\title{
New records of Staffia aenigmatica (Mammalia, Allotheria, Haramiyida) from the Upper Jurassic of Tendaguru in southeastern Tanzania, East Africa
}

\author{
Wolf-Dieter Heinrich'
}

With 6 figures

\begin{abstract}
Two non-multituberculate allothcrian cheek teeth are described from the Upper Jurassic of Tendaguru in southeastern Tanzania. East Africa. Both specimens were collected from dinosaur-bearing matrix of bone bed Wj of the Middle Saurian Bed at Tendaguru Site dy by the German Tendaguru Expedition (1909-1913). Bone Bed Wj represents limnic to brackish deposits of Kimmeridgian-Tithonian age. The cheek teeth, considered as lower posterior molar and upper molar, represent a single taxon of the Haramiyida and are referred to Staffia aenigmatica, known only from the Upper Jurassic of Tendaguru. This assignment reinforces evidence for the palaeogeographic dispersal of haramiyids to Gondwana and the temporal persistence of these non-multituberculate allotherians into the Late Jurassic. Characters that distinguish Staffia aenigmatica from other haramiyids include the medial position of main cusp al at the front of the tooth crown and the presence of a large, anterolingual main notch between cusps a1 and a 2 in lower cheek teeth, as well as the development of a strong anterolabial cingular ridge in the only known upper cheek tooth. Staffia shows the closest resemblance to Thomasia from the Late Triassic to Early Jurassic of Europe, although these genera are disdinctly different. Retention of the basic tooth crown pattern of haramiyids and traces of wear in the Tendaguru teeth suggest that the masticatory movements in Staffio were essentially restricted to a longitudinal direction, as in Thomasia. It is suggestcd that owing to its central position at the front of the tooth crown the lower main cusp al could have occluded in the central basin of the opposing upper molar during masticatory movements.
\end{abstract}

Key words: Mammalia, Allotheria, Haramiyida, Staffia, Upper Jurassic, Tendaguru, Tanzania, East Africa, Gondwana

\section{Zusammenfassung}

Aus dem Oberjura von Tendaguru in Tansania, Ostafrika, werden zwei Backenzähne eines Haramiyiden beschrieben. Beide Zähne stammen aus knochenführenden Gesteinsproben, die von der Deutschen Tendaguru Expedition (1909-1913) in der Fundstclle dy gesammelt wurden. Fundschicht der Haramiyiden-Zähne ist eine knochenführende Lage (Wj) der Mittleren Saurierschicht, die im Zeitraum Kimmeridge-Tithon in einem küstennahen Ablagerungsraum entstand. Beide Backenzähne. ein hinterer unterer Molar und ein oberer Molar, werden zu Staffia aenigmatica gestellt, die bisher nur aus dem Oberjura von Tendaguru bekannt ist. Beide Nachweise bestätigen erneut, daß Haramiaiden einst in Gondwana verbreitet waren und dort noch in der späten Jura-Zeit vorkamen. Merkmale, die Staffia aenigmatica von anderen Haramiyiden unterscheiden. sind die 7.entrale Position des a1-Höckers im Vorderabschnitt der Zahnkrone und die tiefe, breite anterolinguale Furche zwischen dem a1- und a2-Höcker der unteren Backenzähne sowie die starke labiale Cingulumleiste am einzigen bisher bekannten oberen Molaren. Zwischen Staffia aus dem Oberjura Ostafrikas und Thomasia aus der oberen Trias und dem unteren Jura Europas bestehen Gemeinsamkeiten, aber auch wesentliche Unterschiede. Die Beibehaltung des Backenzahn-Grundmusters der Haramiyiden und Abkauungsspuren an den Zähnen aus Tendaguru zeigen, daß die Kaubewegung bei Staffia im wesentlichen in longitudinaler Richtung erfolgte, wie bei Thomasia. Für Staffia wird vermutet, daß der al-Haupthöcker auf Grund seiner zentralen Lage im vorderen Abschnitt der Zahnkrone in das zentrale Becken des entsprechenden oberen Backenzahnes paßte und dort bei der Zerkleinerung von Nahrungspartikeln mitwirkte.

Schlïsselwörter: Mammalia, Allotheria, Haramiyida, Staffia, Oberjura, Tendaguru, Tansania, Ostafrika, Gondwana

\section{Introduction}

Haramiyids are an enigmatic group of non-multituberculate allotherians. They are only known from isolated teeth, except for Haramiyavia clemmensi from the Late Triassic of Greenland that is based upon associated lower and upper jaws with teeth (Jenkins et al. 1997). The origin and phylogenetic relationships of haramiyids have been the subject of much discussion (e.g., Clemens \& Kielan-Jaworowska 1979, Hahn \& Hahn 1983, Hahn et al. 1989. Kielan-Jaworowska

1 Museum für Naturkunde, Institut für Paläontologie, Invalidenstr. 43, D-10115 Berlin, Germany. E-mail: dieter.heinrich@mus.hu-berlin.de

Received June 2001, accepted July 2001 
1992, Butler \&: McIntyre 1994. Butler 2000. Kielan-Jaworowsk a \& Hurum 2001). The earliest representatives of the order Hatamiyida have been reported from the Upper Norian (Upper Middle Keuper) Plat'osaurus Beds of Halberstadt in Central Germany (Thomasia hahni: Hahn 1973. Burler \& Macintyre 1994) and from the? Norian-Rhaetic Tait Bjerg Beds of the Flemming Fjord Formation in East Greenland (Haramivavia clemmensi Jenkins et al. 1997). Most haramiyids have teen recovered from Late Triassic to early Jurassic localities in Central and Western Europe. Described genera include representatives of the families Therotcinidae (Theroteinus: Sigogneau-Russell 1983. Sigogneau-Russell et al. 1986. Butler 2000), and Haramiyidae (Thomasia. including Haramiya: e.g. Plieninger 1847. Branca 1915. Simpson 1928. Parrington 1947. Peyer 1056. Hahn 1973. Clemens 1980. Hahn \& Hahn 1983. Sigognealu-Russell 1989. SigogneauRussell \& Haln 1994. Butler \& MacIntyre 1994. Delsate 1995. 2000. Godefroit ot al. 1998. Butler 2000). More racently. Kermack et al. (1998) described Eleutherodon oxfordensis from the British Middle Jurassic (Bathonian) and proposed the new allotherian suborder Eleutherodontida (order incertae sedis). which was assigned to the order Haramivida by Butler (2000). In addition to the genera mentioned above. possible haramiyids have also been recorded from the Lower Jurassic of North America (Jenkins et al. 1983. Butler 2000) and the Middle Jurassic (Bathonian) of England (Freeman 1976. Butler 2000).

Until recently, haramiyids were unknown outside Laurasia. However, microvertebrate sampling in dinosaur-bearing matrix from the Tendaguru Beds in southeastern Tanzania led. in 1999. to the discovery of Staffia aenigmatica. extending the hitherto known range of haramiyids to the Late Jurassic and the known palaeogeographic distribution of these non-multituberculate allotherians fro $n$ the Northern Hemisphere to Gondwana (Heinrich 1999a).

Staffia aenigmatica is, as yet. a poorly known taxon. The holotype and only known specimen is a moderately well preserved cheek tooth which was tentatively identified as a lower posterior premolar and provisionally placed in the family Haramiyidae (Heinrich 1999a). Unfortunately. the fragmentaly nature of the type specimen did not allow precise conclusions concerning the tooth crown morphology.

Since the first report of a Late Jurassic haramiyid from Gondwana. continued microvertebrate sampling in matrix collected by the Ger- man Tendaguru Expedition (1909-1913) from the Middle Saurian Bed at Tendaguru has resulted in the discovery of two further haramiyid cheek teeth. Both records are particularly important in that they add substantially to the knowledge of Gondwana haramiyids and also contribute significantly to the understanding of the Tendaguru local land vertebrate fauna, thus playing a key role in research on Jurassic faunas of the African mainland.

The results presented here are part of a continuing Tendaguru project of the Institul für Paläontologie der Humboldt-Universität zu Berlin supported by the Deutsche Forschungsgemeinschaft (He 2757/1-3).

\section{Geological and palaentological setting}

Detailed accounts of the geological structure and the stratigraphy of the Mesozoic deposits in the Tendaguru area are given by Hennig (1914, 1937). Janensch (1914a), Aitken (1961), and Kent et al. (1971). A brief summary of these data is presented by Russell et al. (1980) and Heinrich (1999b). Therefore, only a few comments on the stratigraphy of the Tendaguru Beds that are relevant to the description of the nonmultituberculate allotherian remains described below. are noted here.

The stratigraphical terminology follows Janensch (1914a) and Russell et al. (1980). According to Janensch (1914a), the Tendaguru Beds are part of the Lindi Formation, a stratigraphic term introduced by Dacqué \& Krenkel (1909). Stratigraphic names such as Tendaguru Beds, Trigonia smeei Bed and Middle Saurian Bed (Fig. 1) do not meet adequately the international stratigraphic guidelines of the International Union of Geological Sciences. More appropriate names such as Tendaguru Formation or Middle Saurian Member used sporadically in the literature are ignored here, since the introduction of new stratigraphic terms should be based on new lithoand biostratigraphic investigations in the Tendaguru region and these are still in progress (Heinrich et al. 2001).

The Tendaguru Beds, covering large areas in southeastern Tanzania, are best exposed in the surroundings of Tendaguru Hill and most well known for the abundance of dinosaur bones (e.g.. Janensch 1914b, 1929, 1961, Parkinson 1930. Russell et al. 1980, Heinrich 1999b). The sedimentary sequence reaches about $140 \mathrm{~m}$ in thickness and consists of three dinosaur-bearing 
deposits, the Lower, Middle, and Upper Saurian Beds, and three marine sandstone units, the Nerinea Bed, Trigonia smeei Bed and the Trigonia schwarzi Bed (Fig. 1).

Ever since dinosaurs were first discovered in the vicinity of Tendaguru Hill in 1906, the age of the Tendaguru Beds has been the subject of controversial discussion. Although the sequence was once considered as Cretaceous in age (e.g., Fraas 1908, Kitchin 1929), the Tendaguru Beds are now dated as Late Jurassic, except for the Trigonia schwarzi Bed which is equated with the Early Cretaceous (e. g. Dietrich 1933, Aitken 1961, Russell et al. 1980, Heinrich et al. 2001). The age of the haramiyid-bearing deposits will be further discussed below.

The haramiyid material described herein comes from Tendaguru Site dy $(\mathrm{Jg}, \mathrm{Wj})$ that is situated approximately $2.5 \mathrm{~km}$ north-north-west of Tendaguru Hill (Fig. 1). It was recovered from matrix of the Middle Saurian Bed which overlies the Nerinea Bed and underlies the Trigonia smeei Bed in the Tendaguru region (Hennig 1914, Janensch 1914a). The locality was originally named as Site $\mathrm{Jg}$ (Janensch 1914b: 51, map on p. 45) or $\mathrm{Jg}(\mathrm{Wj})$ (Janensch 1925: map on p. XVIII) and later re-named as dy (Janensch 1955: 107 , foot note 1), a symbol that derives from Dysalotosaurus (now Dryosaurus), because the Middle Saurian Bed at this site was found to contain the ornithischian dinosaur Dryosaurus lettowvorbecki, unrecorded elsewhere in the Tendaguru area (Janensch 1955). Site dy was one of the richest and most extensively hand-quarried vertebrate localities in the Tendaguru region (Fig. 2).

The Middle Saurian Bed at Tendaguru Site dy contains two bone-bearing strata, characterized by disarticulated dinosaur bones of Dryosaurus lettowvorbecki that almost completely dominate the deposits (Janensch 1914a, b, 1955; Heinrich 1999b). Apart from Dryosaurus lettowvorbecki only a few isolated stegosaur and sauropod remains have been found (Branca 1914, Janensch 1914a, b). The depositional environment of the Middle Saurian Bed at Tendaguru Site dy was mainly limnic to brackish in origin (Heinrich 1999b).

Unfortunately, Janensch (1914a, 1929, 1955) did not provide profile sketches or unequivocal names for the two above mentioned bone-bearing strata of Tendaguru Site dy. This presents a problem, since the material of Site dy which was designated as $\mathrm{Jg}$ or $\mathrm{Wj}$ cannot be related to either of the two bone beds with certainty. A rediscovered hand-written letter of $\mathrm{H}$. Reck, who directed the excavations at Tendaguru Site dy in 1912 and 1913, was very helpful, as it contains a short comment and a simplified sketch of the profile showing the precise stratigraphic relationships of the two previously-mentioned bone beds (Fig. 3). The comment reads as follows: "Der Graben ist gewiß der gleiche. Aber das Jg Material Hennig's stellt eine scharf begrenzte Knochenansammlung dar, welche im Liegenden meiner Wj Herde ruht. Teilweise liegen die Herden sogar direkt übereinander, jedoch ist eine fossilleere oder doch sehr arme Bank eingeschaltet" (The quarry is certainly the same one. But Hennig's Jg material consists of a sharply-defined bone accumulation, which lies beneath my Wj "herd". In part, the "herds" even lie directly atop one another, however, a non-fossiliferous or at least very (fossil) poor layer is intercalated between them). Consequently, the bone bed $\mathrm{Wj}$. as he defined it, is above bone bed $\mathrm{Jg}$, and it should be noted that the symbols $\mathrm{Jg}$ and $\mathrm{Wj}$ refer merely to two bone-bearing strata in a single site (dy) and do not relate to two different localities in the Tendaguru area. H. Reck's letter, written on February 10, 1914, is of importance as it makes possible, for the first time, to distinguish unequivocally two successive assemblages of terrestrial vertebrates within the Middle Saurian Bed.

Both allotherian cheek teeth described below were obtained from blocks of bone bed $\mathrm{Wj}$, collected during the excavations of the German Tendaguru expedition between 1911 and 1912 at Site dy and housed now in the Museum für Naturkunde Berlin (Institut für Paläontologie). The specimens were hand picked under a microscope from the residue of matrix which was dissolved in acetic acid.

Specimens recovered from the matrix of bone bed $\mathrm{Wj}$ also include skeletal remains of ornithischian dinosaurs (Kentrosaurus aethiopius, Dryosaurus lettowvorbecki), unidentified theropod and sauropod dinosaurs, a dwarf crocodile similar to Bernissartia (Heinrich, unpublished), pterosaurs (Tendaguripterus recki: Unwin \& Heinrich 1999), and the holotype of the haramiyid Staffia aenigmatica (Heinrich 1999a). The mammalian records of Tendagurodon janenschi and Tendagurutherium dietrichi described previously from Tendaguru Site dy (Heinrich 1998) are from bone bed $\mathrm{Jg}$ and associated with a paramacellodid lizard (Broschinski 1999), an unidentified dwarf crocodile (? Bernissartia), and Dryosaurus lettowvorbecki (Heinrich, unpublished). 

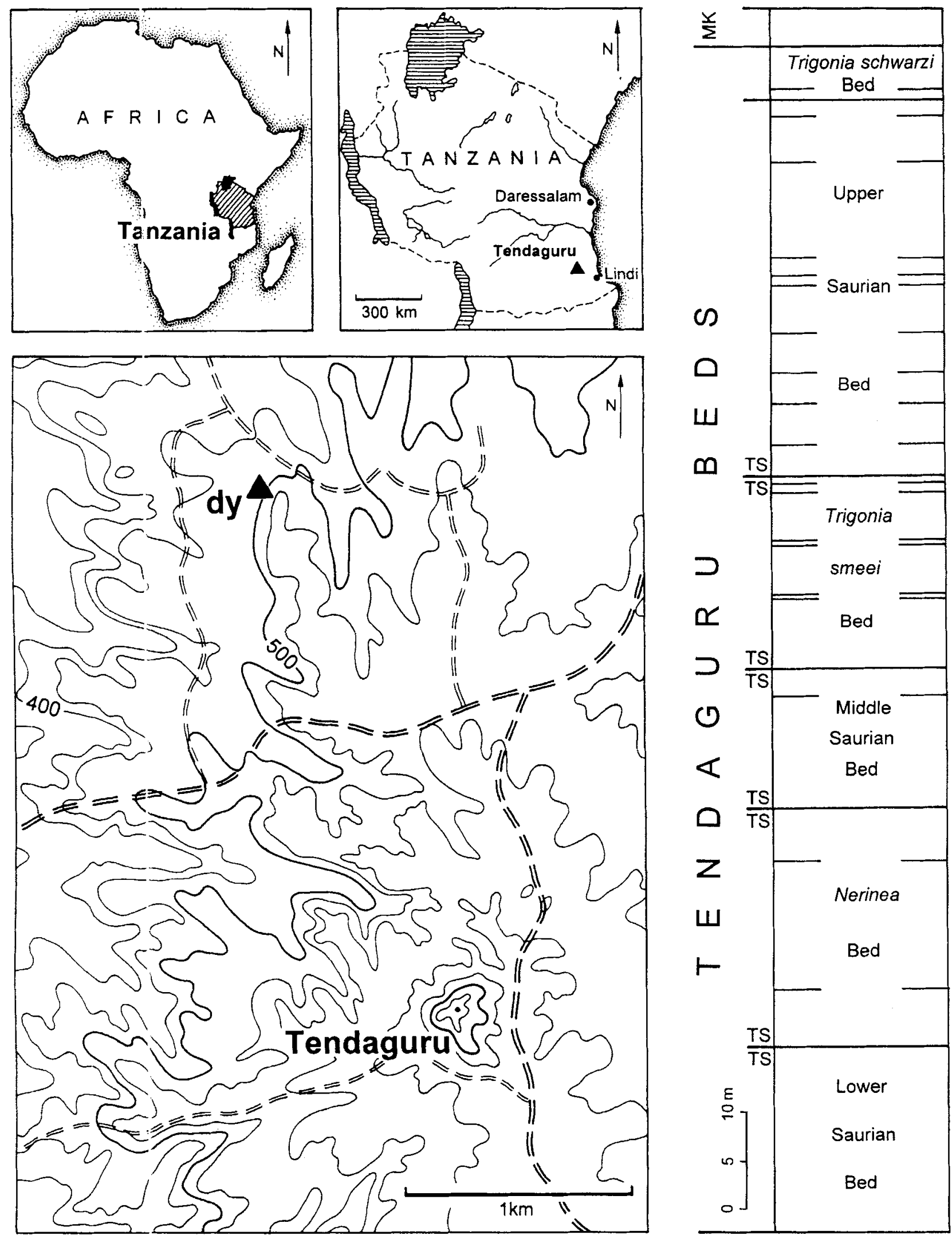

Fig. 1. Map of the Tendaguru area in southwestern Tanzania with a generalized section of the Tendaguru Beds and the topographic location of the mammal-bearing Site $\mathrm{dy}$ considered in present account. TS. Transitional Sands; MK, remains of coarse to pebble-grained lluviatil deposits on top of Tendaguru Hill assigned to the Makonde Bcds by Janensch (1914a), true thickness is not shown. Note also that age of the Makonde Beds is uncertain (see Kent el al. 1971). Contour heights in fect.

Source: Hennig (1914). Janensch (1914a, 1925). Heinrich (1999b): sheet 'Nanjirinje' (no. 283/1) of the topographic maps (scries: Y 742: edition I-TSD). Tanzania. 


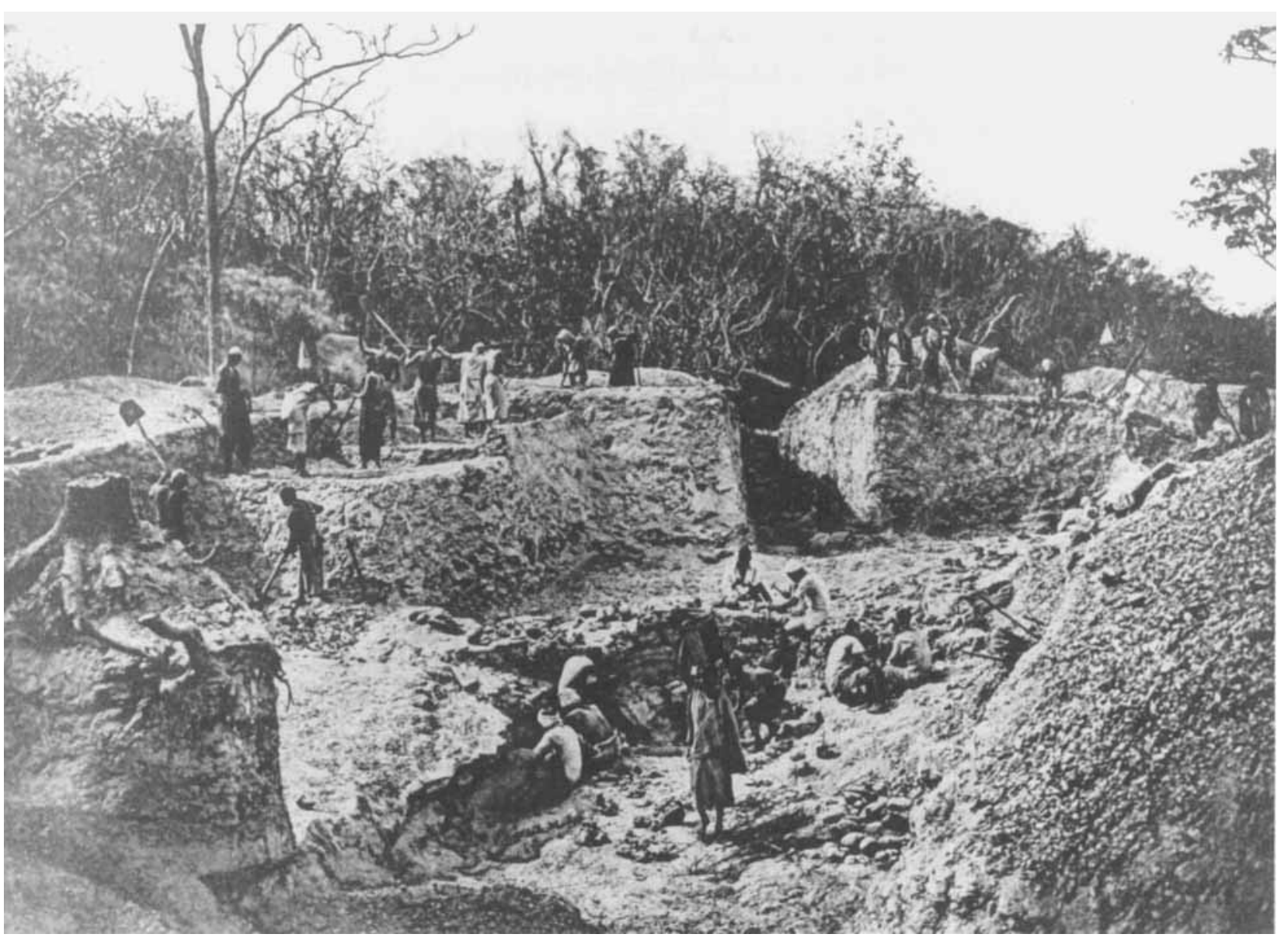

Fig. 2. Photograph of Tendaguru Site dy, the type locality of the haramiyid Staffia aenigmatica. Type specimens of Tendagurodon janenschi. Tendagurutherium dietrichi and Dryosaurus lettowvorbecki have also been recovered here, in cxposures of the Upper Jurassic Middle Saurian Bed. The position of the two super-imposed bone beds Jg and Wj is likely to have been close to the base of the exposure. Photograph by Hans G. Reck in 1912. Source: Institut für Paläontologic der Humboidt-Universität zu Berlin.

Miospore and dinoflagellate assemblages recovered from matrix, housed in the Museum für Naturkunde Berlin (Institut für Paläontologie), suggest a Kimmeridgian to Tithonian age for bone bed Wj (Schrank 1999, 2000), whereas associated charophytes (Schudack 1999) and ostracods (Schudack \& Schudack 2001) indicate a Kimmeridgian age for this bone-bearing deposit. Further biostratigraphic studies are needed to determine more precisely the age of the two bone beds at Tendaguru Site dy.

\section{Cusp terminology}

Tooth crowns of haramiyid check teeth typically have two rows of mesiodistally aligned cusps, a central basin, and an U-shaped ridge connecting both cusp rows (Fig. 4). In lower cheek teeth, the U-shaped ridge is distal and the row with the highest mesial cusp (row A) is lingual (Hahn 1973, Jenkins et al. 1997). Contrary to previous interpretations, however, in upper cheek teeth the U-shaped ridge is mesial and the row of three cusps (row A) is labial (Jenkins et al. 1997). The cusp terminology used in this paper follows Jenkins et al. (1997) and Butler (2000) unless otherwise noted. The cusps are labelled with letters (row symbols) combined with arabic numerals and numbered from mesial to distal in lower cheek teeth, and from distal to mesial in upper cheek teeth (Fig. 4), as suggested by Jenkins et al. (1997) and Butler (2000). Capital letters are used for cusps of upper (maxillary) cheek teeth, lower case letters for those of lower (dentary) cheek teeth. The terms applied here to cusps of non-multituberculate cheek teeth are primarily descriptive and do not imply homologies with cusps of cheek teeth in multituberculate allotherians which are similarily named in the literature. The cusp teminology used is illustrated in Figure 4.

Butler (2000) has recently demonstrated, with reasonable certainty, the cusp homologies of the molariforms in the haramiyids. In the lower molars of Haramiyavia, cusp b2 is placed posterior 


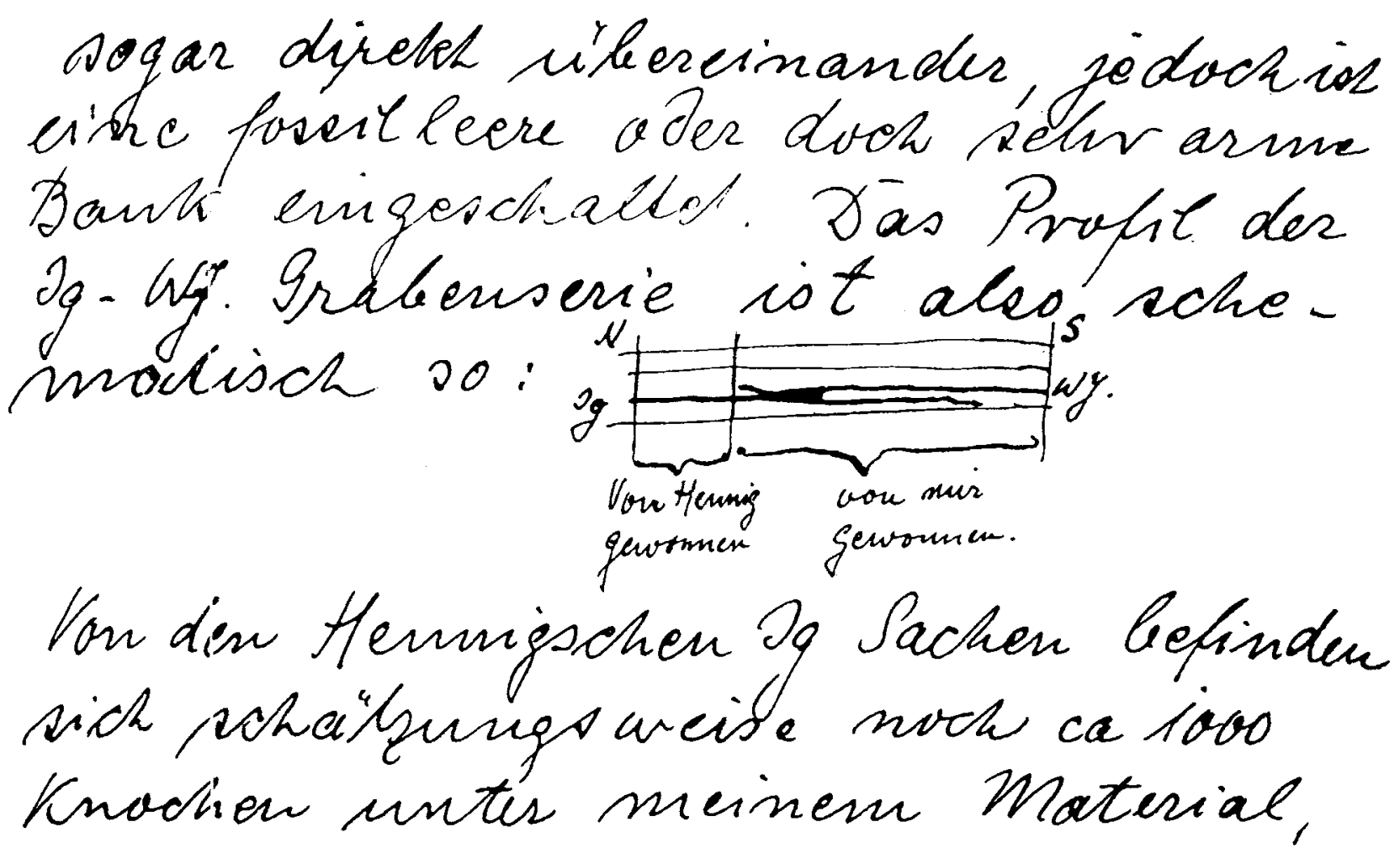

Fig. 3. Excerpt of in unpublished hand-written letter of Hans G. Reck. leader of the German Tendaguru Expedition in 1912 and 1913, showing the superpositional relationships of the two bone-bearing beds $\mathrm{Jg}$ and $\mathrm{Wj}$ exposed at Tendaguru Site dy between 1912 and 1913. The letter dates from February 10. 1914. Source: Institut für Paläontologie der Humboldt-Universität 7.u Berlin.

to the main cuip a1 (Jenkins et al. 1997: 717. fig. 4: Butler 2000: 321. fig. 1). This suggests that the cusp in Thomc sia. that was traditionally considered as b1 (e.g.. Hahn 1973. Sigogneau-Russell 1989, Butler \& McIntyre 1994). is probably homologous $w$ th cusp b2 of Haramiyavia (Butler 2000: 320. f.g. 1) and should be labelled as b2 rather than b1. Since the dental morphology of Staffia is similar to that of Thomasia in several aspects. it is also probable that cusp bl in the Tendaguru specimens (Fig. 4) might be homologous with cusp) b2 in Haramiyavia. as recently suggested by Butler (2000). A distinct swelling on the labial slope of the main cusp al in the type specimen of Staffia aenigmatica, that might be the result of the fusion of cusp al with b1. would support this interpretation (Heinrich 1999a).

However. Thomasia from the Late Triassic to Early Jurassic of Europe and Staffia from the Late Jurassic of East Africa are separated by long temporal interval. Moreover, the available haramiyid material from Tendaguru is too poor to yield definite data regarding cusp homology. More complete material is needed before significant conclusiors can be made. Thus the descriptive cusp termi lology is retained here (Fig. 4).

\section{New fossil material of Staffia}

\section{Lower posterior molar (MB.Ma.50069)}

The crown of the new lower cheek tooth is complete. well preserved, and practically unworn; the root has been broken away. The occlusal outline of the crown is approximately pear-shaped (Fig. 5/1A). The margins of the tooth crown, as seen from above, are rounded, with well developed indentations, especially in the labial and posterior wall, corresponding to the external openings of the notches. The tooth crown is slightly longer than wide, with the greatest width approximately across cusps a2 and b1 (Fig. 5/1 A).

Specimen MB.Ma.50069 exhibits the basic haramiyid tooth crown pattern. The two rows of cusps bordering the central basin are curved (Fig. 5/1A), and each consists of three cusps decreasing gradually in height from front to back (Fig. 5/1B-1C). Cusp row a is slightly higher than row b, with principal cusp al distinctly larger and higher than the other cusps of the tooth crown. In all cusps, the basin surface is steeper than the marginal surface.

The cusp height gradient of row a is: al $>$ a2 $>$ a3. The main cusp a1 is shifted medi- 

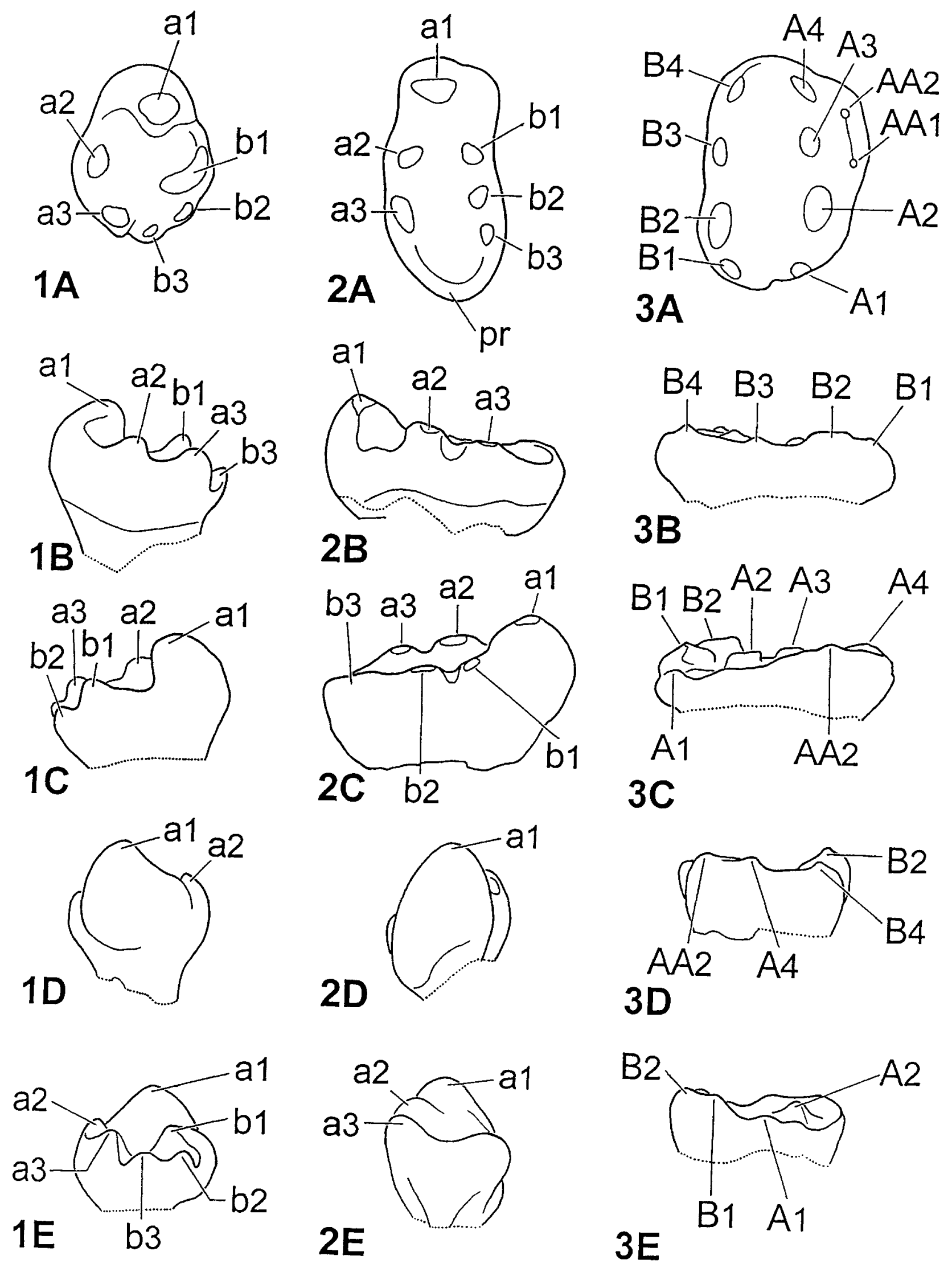

Fig. 4. Dental terminology for cheek teeth of Staffia aenigmatica from the Upper Jurassic of Tendaguru. 1. right lower posterior molar tentatively identified as $\mathrm{m} 3 ; \mathbf{2}$. holotype specimen, tentatively identified as right lower posterior premolar (? anterior molar); 3. left upper molar tentatively identified as M2. Not to scale. The cheek teeth are shown in occlusal (A). lingual (B), labial (C), mesial (D), and distal views (E). a1-a3, lingual cusps of lower cheek teeth (cusp row a); b1--b4, labial cusps of lower cheek teeth (cusp row b); $\mathbf{A 1}-\mathbf{A 4}$, labial cusps of upper cheek teeth (cusp row A); B1-B4, lingual cusps of upper cheek teeth (cusp row B); AA1, AA2, cingular cusps; pr, U-shaped posterior rim. 


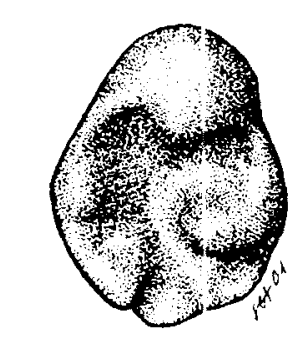

$1 \mathrm{~A}$

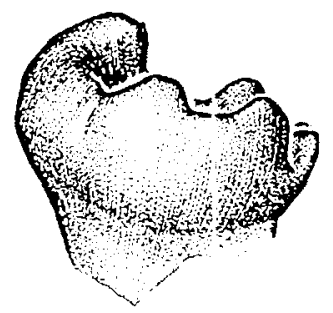

$1 B$

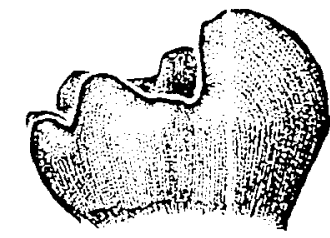

$1 \mathrm{C}$

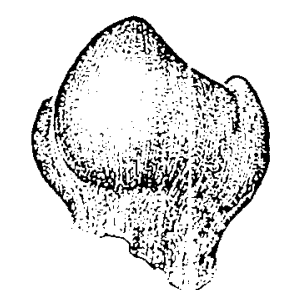

1D

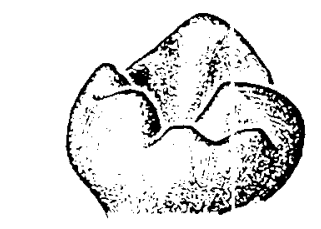

$1 \mathrm{E}$
$2 A$
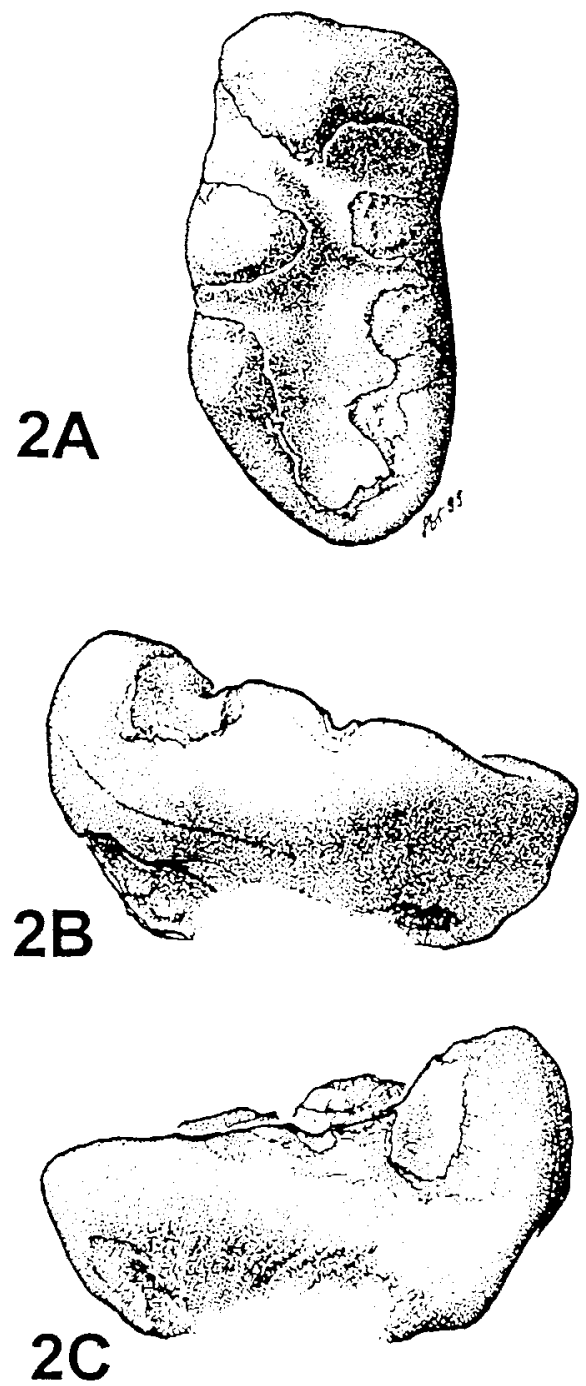

2D
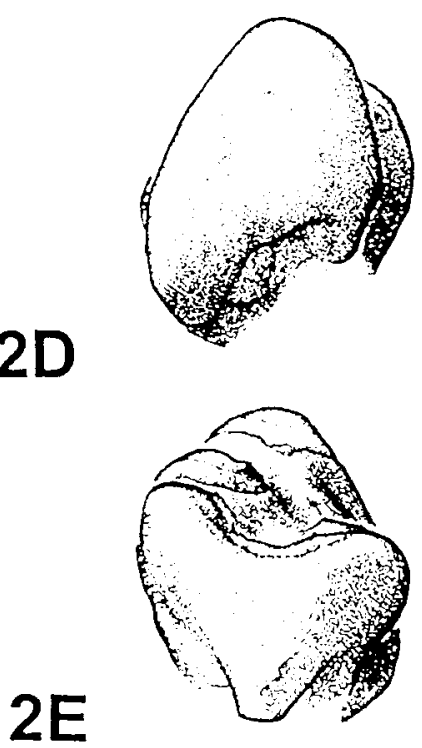
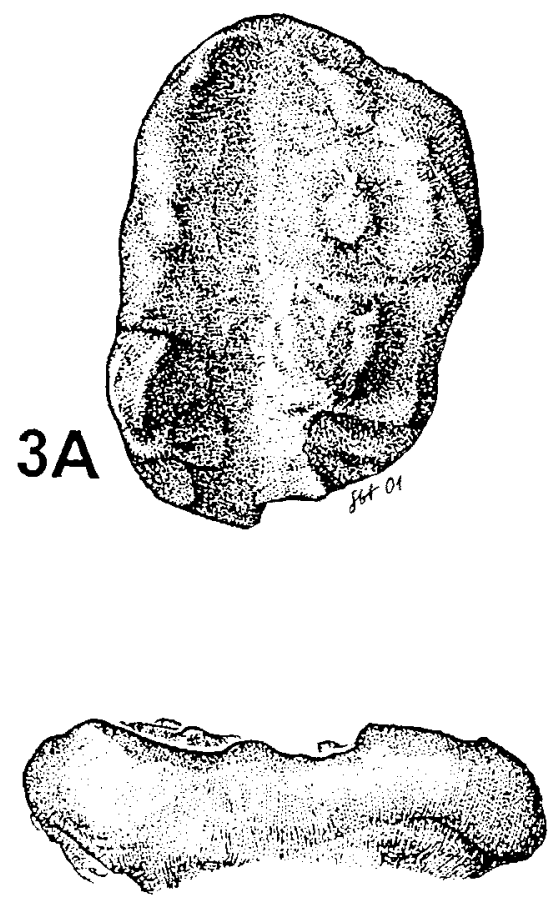

3B

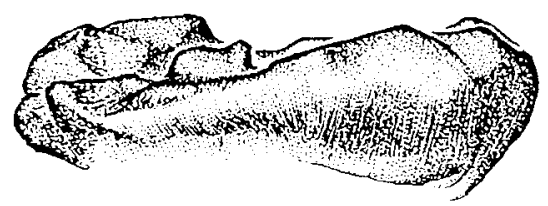

$3 \mathrm{C}$

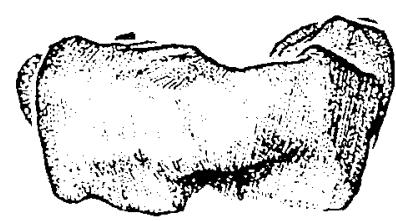

3D

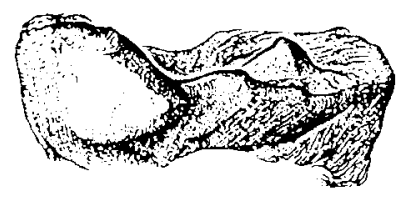

$3 E$

Fig. 5. Suaffia aenigmatica from the Upper Jurassic of Tendaguru in Tanzania. East Africa. 1. MB.Ma.50069, right lower posterior molar. tenta ively identified as m3: 2. MB.48080. type specimen. tentatively identified as right lower posterior premolar (? anterior molar) 3. MB.Ma.50070. left upper molar. tentatively identified as M2. The cheek tecth are shown in occlusal (A). lingual (B). labial (C). mesial (D). and distal views (E). Scale bars $=1 \mathrm{~mm}$. 
ally and located in the longitudinal midline of the tooth crown. When viewed in longitudinal section, principal cusp a1 is remarkably asymmetric, owing to its vaulted anterior and steep posterior face (Fig. 5/1B-1C). Cusp a2 is separated from the preceding main cusp a1 by a large notch, open anterolingually, and with a broad U-shaped floor (Fig. 5/1A-1B). Cusp a2 is much smaller than cusp a1 and distinctly separated from cusp a3 by a well-developed transverse notch. Cusp a3 is slightly lower than a2. The notch separating cusps a 2 and a 3 is distinctly smaller and shallower than that between a1 and a2. (Fig. 5/1B).

Labial cusp row $b$ is sligtly more curved than the lingual row (a), and well-developed notches separate the cusps. Among the three cusps making up row $b, b 1$ is by far the largest. The cusp height gradient of row $b$ is: $b 1>b 2>b 3$. Cusp b1 is separated from the labial slope of the principal cusp a1 by a deep notch, open anterolabially. The basin wall cusp b1 is displaced close to the longitudinal midline of the tooth crown (Fig. 5/1E) and, as seen in occlusal view, drawn out anterolabially into a curved swollen ridge that tapers anteriorly and slopes towards the notch bordered by cusps a1 and b1 (Fig. 5/1A). Cusp b2 is markedly smaller than b1, barely higher than b3 and lies approximately opposite cusp a3. Cusp b3, similar in girth and height to $\mathrm{b} 2$, is displaced into the longitudinal mid-line of the tooth crown. All cusps lack enamel ridges. The U-shaped posterior ridge bears the closely spaced unworn cusps a3, b3, and b2. Cingulids and single accessory cingular cusps are missing.

The central basin is deep and distinctly narrowed by the barrier-like projecting cusp b1 (Fig. 5/1E), broader anteriorly than posteriorly, and with the deepest point close to the rising basin face of cusp b1. The central basin extends anterolingually towards a broad trough-like notch just posterior to principal cusp a1, and it is also linked anterolabially to a deep notch, which has an approximately V-shaped cross section. The posterior portion of the central basin is smaller than the anterior, narrowed by cusps a 3 and b1, and opens externally through two small notches.

The enamel surface of both the central basin and the cusps is smooth: wrinkled (rugose) enamel is not developed. The tip of the principal cusp, a1, is very slightly worn. No evidence of wear was found either on the tops of the other cusps or in the central basin.

On the anterior edge of the tooth crown, there is no indentation (recess) for the reception of the posterior end of the preceding molar. The root is not preserved, but the broken, tearshaped outline of the base of the tooth crown suggests that it extended longitudinally, with the greatest width just below the posterior portion of the central basin. Acessory roots are not present.

The dimensions of the tooth crown are as follows (in $\mathrm{mm}$ ): maximum length (across cusps a1-b3): 0.92, maximum width (across cusps a2-b1): 0.70 .

\section{Upper molar (MB.Ma.50070)}

Even though it has suffered considerable wear and corrosion, enough of the tooth crown is preserved to identify specimen MB.Ma.50070 as an upper molar of a haramiyid. The tooth crown is imperfectly preserved, heavily worn and corroded, with most of the original tooth crown pattern obliterated. The posterolabial portion and the posterior margin of the crown are missing, so that nothing can be said about the structure of the tooth crown in this region. The roots have also been broken away.

The tooth crown tapers anteriorly. Its occlusal outline is asymmetrical because of the strong cingulum crest on the anterolabial flank of the tooth crown (Fig. 5/3A). The anterior margin, as seen from above, is well-preserved, slightly indented, and recedes towards the labial wall of the crown. The lingual margin is nearly straight, but with faintly developed indentations (Fig. 5/3A).

The occlusal surface exhibits the basic haramiyid structure. There is an elongate central basin, flanked on both sides by rows of mesiodistally aligned cusps (row A and B), and a worn. $U$-shaped ridge that joins both cusp rows anteriorly (Fig. 5/3A). From what can be seen of the badly preserved occlusal surface, the lingual cusp row (B) is higher than the labial (A), but the two rows are of approximately the same length. Cusp height gradients cannot be determined owing to the intensive wear that has truncated most of the cusps, especially in the anterior half of both cusp rows.

The labial row of cusps (row A) consists of four approximately aligned cusps, of which the first, A1, is almost completely worn. The presence of this cusp is barely discernible, but the remnants of the cusp base stand well above the deeply excavated central basin, suggesting that a distinct cusp may have been present at an earlier stage of wear (Fig. 5/3E). There is no evidence 
of a saddle-like ridge connecting the posteriormost cusps A1 with B1. Cusp A1 is slightly displaced medially relative to $\mathrm{A} 2$. and separated from the latter by an almost entirely obliterated posterolabial notch. Cusp A2 appears to have been the tallest and largest cusp of row $A$. though this is difficult to assess as the other cusps of row $A$ have been worn almost entirely away. Cusp A.2 is markedly better preserved than the other cusps of row A (Fig. 5/3C. 3E). It bears a feeble. clongate crest and exhibits a steeply inclined arra on its basin face caused. apparently. by wear Nothing can be said about the original morphology of the heavily worn cusps $\mathrm{A} 3$ and $\mathrm{A} 4$, wh ich in oblique light are just distinguishable on the occlusal surface.

B2 appears to have been the largest of the four cusps in the lingual row: the top of the cusp has been replaced by a facet. The preceding cusp, B1. is s ightly displaced medial to main cusp B2 and barely discernible in anterior aspect (Fig. 5/3D). Thr: top of cusp B1 is replaced by an inclined facet. facing posterolingually. Cusps B1 and $\mathrm{B} 2$ are very closely spaced and indistinctly separated by a notch (Fig. 5/3B). sloping towards the basin floor. Cusp B3 is heavily worn and. when viewed $n$ lateral aspect. separated from B2 by a shallow transverse valley. The base of the anteriormost cusp. B4, lies dinstinctly higher than that of B.3 (Fig. 5/3B). The cusps of row B lie slightly pos erior to the corresponding cusps of row A. except for cusp B4 which is approximately oppositt: to A4.

Between the two cusp rows (A, B), there is an elongate central basin that reaches its greatest depth close to the anterior basin slopes of cusps A1 and B1. Tie floor of the central basin appears, in oblique light. as a deeply excavated. narrow. longitudinal groove, indicating extensive wear. This gronve is closer to cusp row B than A. and the lingual basin wall is distinctly steeper than the labia. (Fig. 5/3A, 3E). Anteriorly the basin floor rise; more gradually than posteriorly. and its mesial end is marked by the U-shaped ridge which is vorn to a barely discernible ridge. The posteriormost end of the central basin is broken off. The enamel surface of the central basin and cusfs appears to have been smooth. but clear evidence is lacking due to the imperfect state of prescrvation.

There is a prominent, but imperfectly preserved cingular ridge on the anterolabial edge of the tooth crown. extending from the anterolabial corner of the tooth crown posteriorly. and with evidence of a least two accessory cusps. of which the largest (AA2) is apparently at the front. Accessory cusp AA1 is situated somewhat labial to the notch between cusps A2 and A3, and AA2 lies labial to the groove separating cusps A3 and A4. Cusp row A and the cingular ridge are separated by a shallow furrow, that becomes slightly decper postcriorly.

Two closely spaced contact facets are present on the anterolabial face of the tooth crown, just below cusps A4 and AA2. The roots are broken away, but there appear to have been two of them. a larger transversely broadened root close to the posterior end and a smaller root close to the tapered anterior portion of the tooth crown.

The dimensions of the fragmentary tooth crown are as follows (in $\mathrm{mm}$ ): maximum length: 1.52: maximum width (across cusps B3-AA1): 1.10 .

\section{Comparison and discussion}

Referal of both the upper and lower molar from the Tendaguru Beds to the Allotheria is based on several diagnostic features of the tooth crowns, in particular the two mesiodistally aligned rows of cusps bordering a central basin and the U-shaped ridge linking the two cusp rows. The presence of the labiolingual and mesiodistal reversal of the tooth crown pattern in opposing lower and upper cheek teeth, and the smooth enamel surface in the well-preserved lower posterior molar exclude the posibility that the Tendaguru specimens belong to a multituberculate mammal and support the taxonomic allocation to the non-multituberculate allotherian order Haramiyida.

Serial position. Except for Haramiyavia, the known haramiyid genera and species were exclusively defined upon characters of isolated cheek teeth. Therefore the precise numbers of cheek teeth in Eleutherodon, Theroteinus, Thomasia, and Staffia are unknown. Consequently, the referal of isolated haramiyid cheek teeth from the Tendaguru Beds to a particular serial position is speculative. Assuming that Staffia possessed three lower and upper molars, as found in Haramiyavia (Jenkins et al. 1997) and suggested for Thomasia (Butler 2000), the following tentative conclusions regarding the serial position of the Tendaguru specimens can be made:

The type specimen of Staffia aenigmatica was originally compared with presumed premolars of Thomasia (tooth groop II: Sigogneau-Russell 
1989) and provisionally regarded as a lower posterior premolar (Heinrich 1999a). More recently, Butler (2000) compared the cheek teeth of the Thomasia tooth groop II (Sigogneau-Russell 1989 ) with the lower anterior molar (m1), suggesting that the type specimen of Staffia aenigmatica might represent a $\mathrm{m} 1$.

By comparison with the lower dentition of Haramiyavia and Thomasia, where the ultimate molar is the smallest lower cheek tooth (Jenkins et al. 1997: 717, fig. 4; Butler 2000: 321, fig. 1), it is concluded here that the tiny isolated lower molar from Tendaguru is also likely to be an ultimate lower molar (m3), referred to hereafter as 'm3'.

As further outlined below, specimen MB.Ma. 50070 from Tendaguru shows some similarities with upper cheek teeth from Thomasia, that were originally described as Haramiya tooth group I by Sigogneau-Russell (1989). According to Butler (2000), it seems probable that this tooth group corresponds to the presumed second upper molar in Thomasia, thus the Tendaguru specimen is tentatively regarded as $\mathrm{M} 2$, referred to hereafter as 'M2'.

Affinities. On the basis of the known material the affinities of the Tendaguru haramiyid can be outlined as follows:

Staffia. Despite the different size and serial position, the ' $\mathrm{m} 3$ ' from the Tendaguru Beds shares several diagnostic features with the type specimen of Staffia aenigmatica: (1) a large and deep deep main notch between cusps a1 and a2; (2) the length of the lingual cusp row a, which extends more anteriorly than labial row b; (3) a distinct anterolabial indentation of the buccal margin of the tooth crown; (4) a single-peaked anterior profile and, more importantly; (5) the medial position of main cusp a1 at the front of the tooth crown, indicating the taxonomic affinities of the compared molars.

Taxonomic evaluation of the haramiyid upper molar from the Tendaguru Beds is more difficult, since most of the tooth crown pattern has been worn away. However, there is a feature of the Tendaguru specimen, that suggests that it also derives from Staffia aenigmatica. A key feature of the lower cheek teeth in Staffia aenigmatica is the anterolingual main notch located just posterior to principal cusp a1 (Fig. $5 / 1 \mathrm{~A}-1 \mathrm{~B}$, $2 \mathrm{~A}-2 \mathrm{~B})$. As haramiyid upper molars are both mesiodistal and labiolingual mirror images of the lowers (Clemens \& Kielan-Jaworowska 1979, Butler 2000), a distinct notch in the upper cheek teeth of Staffia aenigmatica should occur in the posterolabial portion of the tooth crown. Though imperfectly preserved, the Tendaguru specimen retains enough morphology to show that such a prominent notch appears to have been developed exactly in the position where it would be expected to occur (Fig. 5/3A). In view of this observations referal of the 'M2' to Staffia aenigmatica is warranted.

Haramiyavia. Characters that distinguish the $\mathrm{m} 3$ of Haramiyavia (Jenkins et al. 1997) from the 'm3' of Staffia are: (1) the basically rectangular shape of the tooth crown; (2) a straight central basin bordered by approximately parallel cusp rows (a, b) and; (3) the position of main cusp a1. which is aligned with cusps a2 and a3. In contrast to Staffia, Haramiyavia has upper molars with a roughly quadrate outline (Jenkins et al. 1997: 416, fig. 1). In both genera, there are four A cusps on M2, of which A2 is the largest. The $B$ row of M2 consists of four cusps in the Tendaguru specimen, of which $\mathrm{B} 2$ is the highest. and five cusps in Haramiyavia, with $\mathrm{B} 1$ as the main cusp in row B (Jenkins et al. 1997: 416, fig. 1). Because of these differences, referal of the two Tendaguru specimens to Haramiyavia appears most unlikely.

Thomasia. The presumed $\mathrm{m} 3$ of Thomasia differs from the 'm3' of Staffia in having: (1) a basically rectangular tooth crown and; (2) a doublepeaked anterior profile (e.g., Thomasia sp: Parrington 1947: 714, fig. 4c, pl. 1, fig. 4a, b; Thomasia tooth group I Sigogneau-Russell 1989: 140-151, fig. 7; Thomasia sp., Butler \& MacIntyre 1994: 443, figs 4, 9h, i; Thomasia sp., Butler 2000: 321, fig. 1). Moreover, the supposed $\mathrm{m} 3$ of Thomasia lacks the large notch separating cusps a1 and a2, a key character of Staffia that distinguishes it from Thomasia.

Owing to the fragmentary nature of the 'M2' of Staffia comparison with Thomasia is tentative. On the upper molars, there are three A cusps in Thomasia, but four A cusps in Staffia, although A2 is the principal cusp in both genera. In Staffia, cusp row A is as long as row B, as in the Haramiya tooth group I sensu Sigogneau-Russell (1989). A striking difference between these taxa is the presence of a strong anterolabial cingular ridge in Staffia, a condition unlike that in other haramiyids, including Thomasia, where only small cuspules or incipient cingula occasionally occur (Sigogneau-Russell 1989, Butler 2000), possibly foreshadowing the condition in Staffia. The differences in the dental morphology out- 
lined above indicate that the Tendaguru specimen are not $r \in$ ferable to Thomasia.

The dimensions of the type specimen of Staffia (length: $2.1 \mathrm{~mm}$ : width: $1.0 \mathrm{~mm}$ ) fall within the size range of that of Thomasia (tooth group II sensu Sigognealu-Russell 1989), length: 1.36-2.17 $\mathrm{mm}$, width: $0.84-1.17 \mathrm{~mm}$ ). This is also true for the incomplete 'M2' from Tendaguru (MB. Ma. 50070, length: $1.52 \mathrm{~mm}$. width: $1.10 \mathrm{~mm}$ : Haramiya tooth group I sensu Sigogneau-Russell 1989. length: $1.43-2.22 \mathrm{~mm}$, width: $1.10-1.88$ $\mathrm{mm})$. By contrast. the ' $\mathrm{m} 3$ ' from the Tendaguru Beds (MB.Ma. 50069: length $0.92 \mathrm{~mm}$. width: 0.70 $\mathrm{mm}$ ) is considurably smaller than the size range in Thomasia (tooth group I. Sigogneau-Russell 1989. length: $1.09-2.49$. width $0.74-1.61 \mathrm{~mm}$ ). The data suggests, that Staffia had a cheek tooth dentition similar in size to that of Thomasia.

Eleutherodon. Cheek teeth of Eleutherodon from the Midclle Jurassic of England (Kermack et al. 1998, Butler 2000) differ markedly from the Tendaguru specimens in having: (1) upper molars with a varying number of up to ten buccal cusps: (2) lower molars with a labial cusp row that is higher than the lingual row, a varying number of up to 21 cusps, and cusp b1 located mesially to cus ) a1: (3) the presence of accessory cusps on the lingual margin of the upper molars and; (4) the presence of distinct enamel ridges (fluting) in lower and upper molars. Eleutherodon is one of t te most distinctive haramiyids and a close relationship to Staffia is unlikely.

Theroteinus. The cheek teeth of Theroteinus from the Late Triassic of Europe (e.g., Sigogneau-Russell 1983, Sigogneau-Russell et al. 1986. Hahn et al. 1989. Butler 2000) display several differences from the molars assigned to Staffia. including: (1) low and blunt lower and upper molar cusps; (2) the presence of additional lingual cusps, instead of labial cusps, on the upper molars and: (3) the short central basin on the lower molars bordered by a lingual cusp row with only two cusps (a1 and a2: Butler 2000). In view of these differences, the specimens from the Tendaguru Beds are not attributable to Theroteinus.

The number of cheek teeth from the Tendaguru Beds is too small to allow detailed comparisons, and more definite statements of the affinities of Staffia must await the recovery of better preserved mat $\epsilon$ rial. The available information on the dental morphology and size of the cheek teeth suggests that the records from the Middle Saurian Bed are best assignable to Staffia aenigmatica. In com sarison with the known haramiyid taxa. Staffia resembles more closely Thomasia than Haramiyavia, Theroteinus or Eleutherodon.

On the basis of the new material, the original diagnosis for Staffia aenigmatica (Heinrich 1999a) can be modified as follows:

Revised diagnosis. Lower posterior premolar (? lower anterior molar): Tooth crown elongate, slightly pinched in the anterior portion, tapered posteriorly, with two approximately aligned main cusp rows ( $a, b)$, bordering an elongate central basin; double-rooted. Row a, higher than row b, with three cusps, of which a1 is the highest. Cusp height gradient: a1 $>$ a2 $>$ a3. Main cusp a1 displaced medially, and positioned at the front of the tooth crown. Row $b$ with three cusps, cusp height gradient: b1 $>$ b2 $>$ b3. Central basin closed by main cusp a1 mesially, and a large U-shaped ridge distally, but open through the anterolingual main notch and a deep anterolabial notch. The remaining notches are distinctly smaller, and noticeably narrower and shallower. The enamel surface is smooth.

Lower posterior molar ('m3'): Tooth crown noticeably reduced in size, pear-shaped in occlusal view, with two slightly curved cusp rows (a, b): single-rooted. Cusp height gradients: $\mathrm{b} 1>\mathrm{b} 2>\mathrm{b} 3$ and $\mathrm{b} 1>\mathrm{b} 2>\mathrm{b} 3$. Row a higher than row b. Principal cusp a1 displaced into a central position at the front of the tooth crown. Central basin narrowed by cusp b1, but open through the anterolingual main notch and a large anterolabial notch. Notches separating the cusps in the posterior portion of the tooth crown distinctly smaller and noticeably narrower and shallower. U-shaped ridge cusped. Enamel surface is smooth.

Intermediate upper molar ('M2'): Tooth crown tapered anteriorly, with an elongate central basin and two main rows of cups, of which cusp row $\mathrm{B}$ is higher than $\mathrm{A}$. There are four A cusps, $\mathrm{A} 1-\mathrm{A} 4$, of which $\mathrm{A} 2$ is the highest, and four $\mathrm{B}$ cusps. B1-B4, with $\mathrm{B} 2$ as main cusp in row $\mathrm{B}$, and a strong anterolabial cusped cingular ridge, that considerably broadened the width of the tooth crown. The enamel surface is probably smooth, as in the lower cheek teeth.

\section{Occlusion}

Despite the discovery of two further molars, conclusions concerning the pattern of occlusion and chewing in Staffia remain uncertain, owing to the incompletely known dentition. The wear topo- 
graphy of the 'M2' is difficult to decipher. Except for A2, nearly all cusps have been worn almost entirely away and most indications of the the original tooth crown pattern have been obliterated. B1 has a well-defined patch of wear, inclined posterolingually. There is a triangular wear facet on cusp B2, tapered anteriorly and inclined slightly lingually. There are possible traces of abrasion on the cingulum ridge, due perhaps to contact with food. Further evidence of wear is visible in the central basin, wherein the floor has been deeply planed, forming an elongate groove. There also seems to be an elongate strip of wear just below the external (lingual) wall of the worn cusp row B. By contrast, ' $\mathrm{m} 3$ ' is almost unworn and displays the original crown pattern in all details. Only the top of main cusp a1 exhibits faint traces of wear.

As mentioned above, the crown pattern of the Tendaguru specimens resembles more closely that of Thomasia than the remaining haramiyid genera, suggesting that occlusion in Staffia might have been also similar to that of Thomasia.

In Thomasia, occlusal movements were mainly restricted to a longitudinal (palinal) direction due to the specific cusp configuration of both lower and upper cheek teeth (Butler \& MacIntyre 1994). According to Butler (2000), labial cusp row $b$ of the lower molars of Thomasia occluded in the central basin between rows $\mathrm{A}$ and $\mathrm{B}$ of the upper molars, and lingual row $B$ of the upper molars occluded in the central basin between cusp rows a and b of the lower molars (Fig. 6A). Consequently, transverse masticatory movements could not occur when the cheek teeth were in occlusion (Butler \& MacIntyre 1994).

The distinct, straight groove in the central basin of the 'M2' of Staffia is interpreted here as strong evidence of wear owing to longitudinal occlusal (palinal) movements, with cusp row B fitting into the central basin of the opposing lower tooth and cusp row $b$ fitting into the central basin of the opposing upper molar (Fig. 6B), as previously postulated for Thomasia by Butler \& MacIntyre (1994) and Butler (2000).

However, there are some striking differences in the dental pattern of Staffia. In particular, the central position of the main cusp a1 which is located at the front of the cheek tooth crown. This suggests that the occlusion pattern in the Tendaguru haramiyid must have been somewhat different from that in Thomasia, where the main cusp a1 is only displaced medially on the supposed lower posterior premolar (tooth groop II sensu Sigogneau-Russell 1989).
Considering the specific cusp configuration of the lower cheek teeth as well as the condition of the central basin of the 'M2' from Tendaguru, it is tentatively concluded here, that, in contrast to Thomasia, the main cusp al of the lower molars occluded in the central basin of the opposing upper molars, as illustrated in Figure $6 \mathrm{~B}$. If so, the main cusp a1 must have undergone a remarkable evolutionary change. In haramiyids, cusp rows a and A have mainly a cutting function, whilst cusp rows $b$ and $B$ primarily crush and grind the food items accumulated in the central basins (Fig. 6A). If properly interpreted, Staffia differs considerably from this pattern. Owing to its central position at the front of the tooth crown, cusp a1 might have been able to travel, with the cusps of row $b$, along the central basin of the opposing upper molar (Fig. 6B), suggesting a functional shift of main cusp a1 from a cutting to a crushing and grinding action.

The model presented here was criticised by $P$. Butler (pers. comm. of July 4, 2001), who proposed that the large anterior cusp on the ' $\mathrm{m} 3$ ' interpreted here as the a1 cusp (Figs 4/1 A-1E. $5 / 1 \mathrm{~A}-1 \mathrm{E}$ ) might represent cusp b2 (sensu Butler 2000) which, during occlusion, follows the rest of the $b$ row along the central basin of the opposing upper molar, whilst cusps a1 and a2 pass lingual to the upper B row. Further, Butler suggests that the link between cusp a1 and a2 on the " $m 3$ ' is the "saddle", and that the large anterior cusp of the type specimen (Figs 4/2A-2E, 5/2A-2E) would have to be identified as cusp b2 (sensu Butler 2000) or b2 fused with a1, in that it is a crushing-grinding cusp and not a shearing cusp like a1 of Thomasia. If the large anterior cusp is really b2 (sensu Butler 2000), the suggested functional change discussed above would not be necessary.

My putative identification of the large anterior cusp of the lower molariforms in Staffia is primarily based on observations of features of the type specimen (Fig. 5/2A-2E), in particular, the presence of a low rounded ridge connecting cusp b2 (sensu Butler 2000) with principal cusp a1 that might have resulted from fusion of cusp a1 with b1 (Heinrich 1999). This "saddle" is positioned in the anterolabial portion of the tooth crown and not in the anterolingual region which is dominated by the main notch between cusps a1 and a2. A similar condition is found in ' $\mathrm{m} 3$ ' in that cusp b1 is drawn out to a rounded ridgelike structure (Fig. 5/1A), more likely to be a "saddle" than that between cusps a1 and a2. 

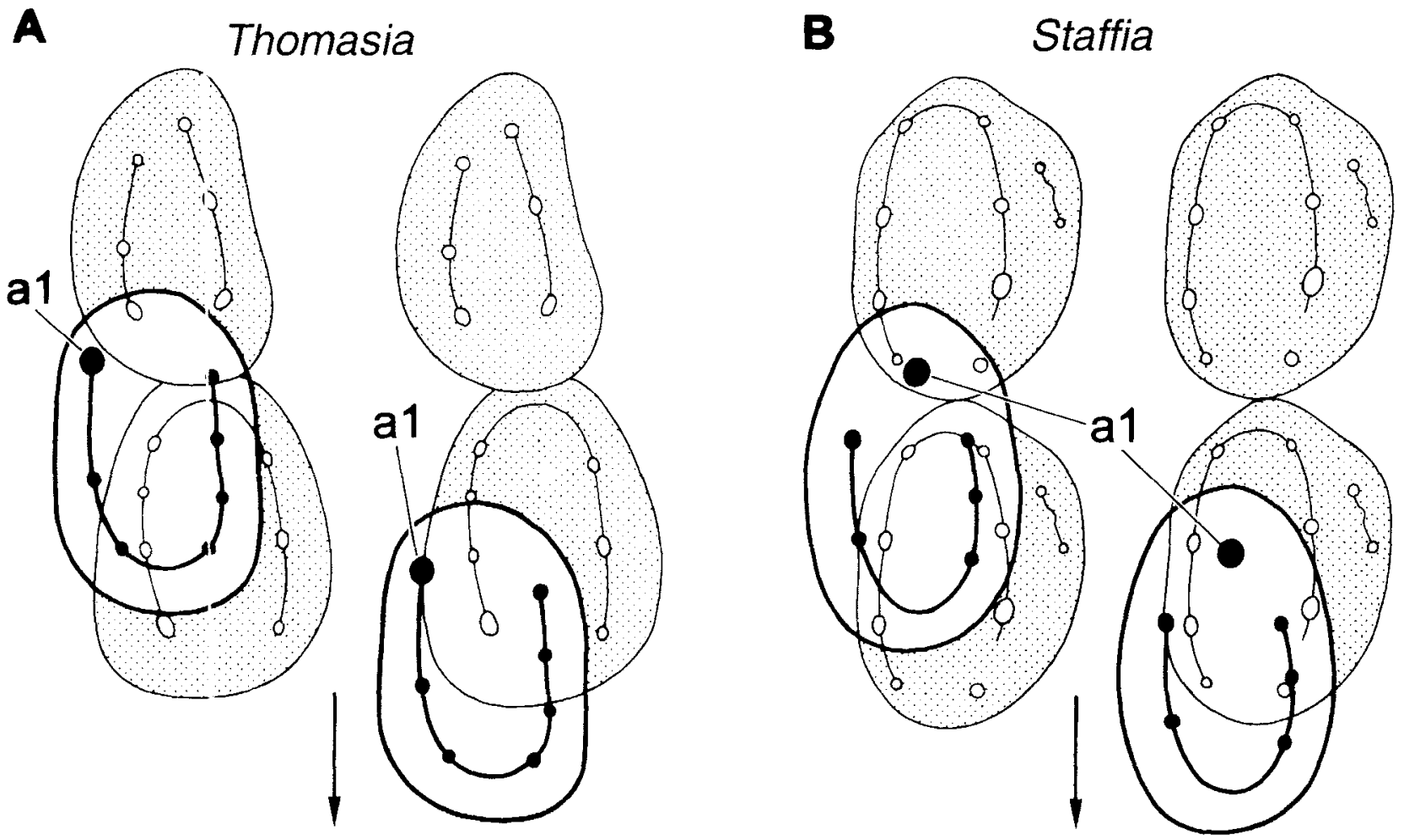

Fig. 6. Diagrammatic representation of putative molar occlusal relations for Thomasia (A) and Staffia (B). The tceth are shown in crown vi 2 w. To emphasize the relative positions of main cusp al during the occlusal movements, the drawings of a lower molar are stperimposed on drawings of upper molars (stippled). Lingual to the left, mesial above. The diagram shows the relative positic $n$ of the lower molars in relation to two opposing upper molars at the beginning (left) and at the end of the occlusal power stroke (right). During the occlusal movements. the lower molar moved postcriorly (arrows). In Thomasia, cusp row a of the lower molars closes with main cusp al lingually to cusp row B of the opposing upper molar. In Staffia, main cusp al of the lower molars occluded with row $\mathrm{b}$ in the central basin between row $\mathrm{A}$ and $\mathrm{B}$ of the opposing upper molar, because of its central position at the front of the tooth crown. For further explanations see text. Fig. A modificd from Butler $(2000)$.

P. Butler (pers. comm. of July 3, 2001) doubted that there was a transitional condition wherein cusp it "jumped" across the upper B row. I agree and $\mathrm{P}$. Butler's objection is important as it might indicate that Thomasia did not give rise to Siaffia. More likely is that Staffia evolved from a lineage that originally had lower molariforms $w$ th main cusp al in the anterior central position. Better preserved and more complete material is needed before definite conclusions regarding occlusion in Staffia can be made.

\section{Conclusions}

Two non-multituberculate allotherian cheek teeth, tentatively identified as a lower posterior molar ( $\left.\mathrm{m} 3^{\prime}\right)$ and an intermediate upper molar ('M2'), are reported from the Upper Jurassic of Tendaguru. Tanzania, East Africa. Both records were obtained from matrix of bone bed $\mathrm{Wj}$ of the Middle Saurian Bed at Tendaguru Site dy through the application of the acid technique. Unfortunately, the 'M2' is not only heavily worn but also corroded, due to transport and sorting prior to burial.

The new allotherian records are interpreted as representing a single haramiyid species and referred to Staffia aenigmatica, which was previously known only from an isolated lower cheek tooth of Tendaguru Site dy (Heinrich 1999a).

The dental morphology of Staffia is compared with that of the known haramiyid genera and shows some similarities with Thomasia. However, Staffia displays several features, that clearly separate it from Thomasia and the other haramiyid genera. A conspicous difference in the prescrved lower cheek teeth of Staffia is the central position of principal cusp a1 at the front of the tooth crown and the presence of a large main notch between cusps a1 and a2. The upper cheek teeth of Staffia differ from Thomasia and other haramiyids, as far as can be judged from an imperfectly preserved upper molar, by the presence of four A and four B cusps, and the strong anterolabial cusped cingular ridge. This ridge broadens the width of the tooth crown considerably and increases the number of cusps. A 
comparison of dental dimensions of Staffia with those in Thomasia shows no substantial differences, except for the ' $\mathrm{m} 3$ ' that seems to be distinctly smaller in the Tendaguru taxon.

The fragmentary nature of the Tendaguru specimens does not permit definite conclusions concerning occlusion in Staffia. In contrast to Thomasia, the main cusp a1 in Staffia might have been able to occlude in the central basin of the opposing upper molar, indicating a functional shift of this cusp mainly from a cutting to a crushing and grinding action.

Owing to the differences described above, Staffia may represent a new lineage of haramiyids and might belong to a new family of these non-multituberculate allotherians, however, erecting new taxa above the genus level should await the discovery of more complete material.

Until the discovery of Staffia aenigmatica in 1999, haramiyids were unknown outside Laurasia. The findings from Tendaguru are the only known records of haramiyids from the Late Jurassic and from Gondwana. Staffia aenigmatica from the Upper Jurassic of Tendaguru is younger than any other haramiyid yet discovered, and it has, like other haramiyids, no known descendents. The origin and phylogenetic relationships of Staffia are poorly understood.

In comparison with the diverse dinosaur assemblage, the knowledge of mammals from the Upper Jurassic of Tendaguru is still limited. However, the recovery of Brancatherulum tendagurense (Dietrich 1927, Simpson 1928, Heinrich 1991), Tendagurodon janenschi, Tendagurutherium dietrichi (Heinrich 1998, 1999a), and, in particular, the unexpected discovery of Staffia aenigmatica, reveal that the associated mammalian assemblage appears to have been correspondingly diverse, even though mammals are among the rarest terrestrial vertebrates in the Tendaguru local fauna.

The mammalian assemblage from the Upper Jurassic of Tendaguru shows some peculiarities, suggesting the existence of a distinct East African faunal province (Heinrich 1999a). For example, the Tendaguru local fauna lacks multituberculate mammals, which are common elements in Late Jurassic faunas of the Northern Hemisphere (e.g., Clemens \& Kielan-Jaworowska 1979, Kielan-Jaworowska \& Ensom 1992, KielanJaworowska \& Hurum 2001), but it contains haramiyids, which, in turn, are so far unrecorded in the Upper Jurassic of Laurasia. If collecting bias can be excluded, this absence may indicate barriers (filters) to the dispersal of multituberculate mammals, even though a land connection (e.g., Smith et al. 1994, Galonka 2000) and limited faunal interchange of land vertebrates between Africa and Laurasia occurred sometime during the Late Jurassic (e.g., Galton 1977, 1982; Sigogneau-Russell 1991a, b; Kielan-Jaworowska 1992. Goodwin et al. 1999). However, multituberculate mammals have been reported from the Lower Cretaceous of mainland Africa (Sigogneau-Russell 1991a), thus the absence of these allotherians in the Tendaguru fauna may simply reflect local ecological conditions.

The presence of calcretes in the mammal-bearing strata of Tendaguru indicate semi-arid to arid climatic conditions, interrupted by seasonal rainfalls when the sediments were deposited (Heinrich et al. 2001). Therefore, the Tendaguru haramiyid Staffia aenigmatica and the associated terrestrial vertebrate assemblage is presumed to have existed in a distinct East African faunal province under a dry climate with seasonally rainy intervals, allowing the persistence of allotherian clades, such as the haramiyids.

\section{Acknowledgements}

I am very grateful to Prof. Dr. P. M. Butler. University of London, and Prof. Dr. W. A. Clemens, Museum of Paleontology, Berkeley, for the opportunity to demonstrate and discuss the Tendaguru mammals during the International Symposium "Origin and Evolutionary Transformation of Mammals - Using biological signals in understanding earth history" held in May 2000 in Berlin. I am most indebted to Prof. Dr. P. M. Butler, University of London, Dr. D. Sigogneau-Russell, Muséum National d'Histoire Naturelle Paris. the late Prof. Dr. B. Krebs (formerly Freie Universität Berlin), and Dr. Th. Martin (Freie Universität Berlin) for helpful comments. Prof. F. Jenkins, Harvard University Cambridge, is thanked for slides of Haramiyavia and remarks on the haramiyid specimens from Tendaguru. My sincere thanks are due to Dr. D. Unwin, Museum für Naturkunde der HumboldtUniversität zu Berlin, Institut für Paläontologie, for criticism on the manuscript and improvements to the English. My sincere thanks are extended to Mr. J. Mendau. Museum für Naturkunde der Humboldt-Universität zu Berlin, Institut für Paläontologie, for drawings and to Mrs. E. Siebert. from the same institution, for the camera lucida drawings in Figure 5. Financial support from the Deutsche Forschungsgemeinschaft (He 2757/1-3) is gratefully acknowledged.

\section{References}

Aitken, W. G. 1961. Geology and Palaeontology of the Jurassic and Cretaceous of Southern Tanganyika. - Bulletin of the Geological Survey of Tanganyika 31: $1-144$.

Branca, W. 1914: Kurzer Bericht über die von Dr. Reck erzielten Ergebnisse im vierten Grabungsjahre 1912. - Archiv für Biontologie 3 (1): 59-63.

- 1915. Einige Betrachtungen über die ältesten Säuger der Trias- und Liaszeit. - Abhandlungen der Könjglich PreuBischen Akademie der Wissenschaften, Physikalisch-Mathematische Klasse 1915 (5): 1-77. 
Broschinski. A. 1599. Ein Lacertilier (Scincomopha. Paramacellodidae) aus dem Oberen Jura von lendaguru (Tansania). - Mitteilungen aus dem Muscum für Naturkund Berlin. Geowissenschaftliche Reihe 2: $157-158$.

Butler. P. M. 2000 Review of he early allotherian mammals. Acta Palaeo tologica Polonica 45 (4): 317-342.

Butler. P. M. \& Macintrre. G. T. 1994. Reriew of the British Haramiyidae (? Mammalia. Allotheria). their molar occlusion and relationships. - Philosophical Transactions of the Royal Socisty of London 345: $+33-4.88$.

Clemens. W. A. 1480. Rhaeto-Liassie mammals from Switzerland and West-Germany. - Zitteliana \$: 51-92.

Clemens. W. A. \& Kielan-Jaworowska. Z. 1979. Multibuberculata. In Lill graven. J. A. Kielan-Jaworowska. Z. and Clemens, W. A. (eds). Mesozoic Manmals. The First Two-thirds of Mammalian History: 99-149. Lniversity of California Press. Berkely

Dacqué. E. \& Kronkcl. E. 1909. Jura und Kroide in Ostafrika. - Neues iahrbuch für Mineralogie. Geolologie und Paläontologie. Beil-Bd. 28: 190-232.

Delsate. D. 1995. Unc nouvelle dent d'Haramividae (Tho-

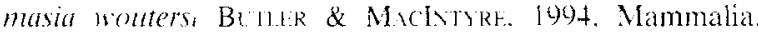
Allotheria) du Rhétien d'Habaya-laVicille (Lorraine. Belge). - Bulletin de la Société belge de Géologie 104 (1/2): $23-34$.

- 2000: Fannes des Vertébres du Thétion (Trias supérieur) du Grand-Duché de Luxembourg. - Archives Institut Grand-Ducal de Luxembourg. Section Sciences naturelles. physiques et mathématiques, nouv. ser. 43:3-47.

Dietrich. W. O. 1927. Brancatherulum n. g.. cin Proplacentalier aus dem ob sisten Jura des Tendaguru in Deutsch-Ostafrika. - Cont alblatt Mineralogic. Geologic und Palaiontologie. Abt. B 1927 (10): $423-+26$.

- 1933, Zur Stratigraphie und Palaeontologie der Tendaguruschichten. Pélacontographica. Supplement VII 12. Reihe. Teil II. Licterung 1): 1-86.

Frats. E. 1908 . Ostatrikanische Dinosaurier. - Palaeontographica 55: $105-144$.

Freeman. E. F. 1076. A mammalian fossil from the Forest Marble (Middl: Jurassic) of Dorset. - Proceedines of the Geological Association 87 (2): $231-235$

Godefroit. P. Culy, G.. Delsate. D. Roche. M. 1998. Late Triassic Vertebrates from Siren (Luxembourg). - Neues Jahrbuch für Geologie und Paläontologie. Abh. 210 $305-343$.

Galonkat. J. 2000. Cambrian-Neogene plate tectonics maps 125 pp. Universvtet Jagicllonski. Kraków

Gaton. P.M. 1977 The orithopod dinosaur Dryosmats and a Laurasia-Gondwanaland connection in the Lpper Jurassic. - Nature 268: 230-2.32.

- 1982. Elaphrositurus. an ornithomimid dinosaur from the Upper Jurassic of North America and Alricat. - Palantologische Zeitsc urift $56(3 / 4): 265-275$

Goodwin. M.B., C emens. W. A.. Hutchinson. J. H.. Wood. C. B. Zavada. M. S. Kemp. A.. Duffin. Ch. J. \& Schaff. Ch. R. 1999. Meso;oic continental vertebrates with associated palynostratigra hic dates from the northwestert Ethiopian plateau. - Journal of Vertchrate Paleontology 19 (4): $728-741$.

Hahn. G. 1973. Nouc Zähne von Haramividen aus der deutschen Ober-Trias und ihre Bezichungen ru den Multituberculaten. - l'alaeontographica, A 142: $1-15$

Hahn. G. \& Hahn R. 1983. Multituberculata. - Fossilum Catalogue I: Ani nalia. pars 127. 409 pp.. Kugler Publications, Amsterdant.

Hahn. G. Sigogn au-Russell. D. \& Wouters. G. 1989. New data on Thero einidae - their relations with Paulchoffatiidac and Haramividae. - Geologica et Palacontologica 23: $20,-215$.

Hcinrich. W.D. Gy. Uber Brancathemban lentagarense DIETRICH. 192- (Mammalia: Eupantotheria) aus dem Oberjura von Tendaguru. Tansania. Vorläufige Mitteilung. - Mittcilungen aus dem Zoologischen Museum Berlin $67(1): 5-104$
- 1998. Late Jurassic mammals from Tendaguru, Tanzania East Africa. - Journal of Mammalian Evolution 5 (4): $269-290$

- 1999a. First haramivid (Mammalia, Allotheria) from the Mesozoic of Gondwana. - Mitteilungen aus dem Museum für Naturkunde in Berlin. Geowissenschaftliche Reihe 2: $159-170$.

$-1999 \mathrm{~b}$. The taphonomy of dinosaurs from the Upper Jurassic of Tendaguru. Tanzania (East Africa), based on ficld sketches of the German Tendaguru expedition (1909-1913). - Mitteilungen aus dem Museum für Naturkunde in Berlin. Growissenschaftliche Reihe 2: 25-61.

Heinrich. W.-D., Bussert. R., Aberhan, M., Hampe, O., Kapilima S.. Schrank. E.. Schultka. St., Maier,G., Msaky, E., Sames. B. Chami. R. 2001. The German-Tanzanian Tendaguru Expedition 2000. - Mitteilungen aus dem Museum für Naturkunde in Berlin, Geowissenschaftliche Reihe 4: 223-237.

Hennig. E.. 1914. Beiträge zur Geologie und Stratigraphie Duutsch-Ostalrikas. - 1. Geologisch-stratigraphische Beobachtungen im Küstcngebiete des südlichen DeutschOstafrika. II. Geologisch-stratigraphische Beobachtungen in Gehiet der Jura-Ablagerungen an der Deutsch-ostafrikanischen Zentralbahn. - Archiv für Biontologie 3 (3): $1-72$

- 1937. Der Sedimentstreifen des Lindi-Kilwa-Hinterlandes (Deutsch-Ostafrika). - Palacontographica, Supplement VII ( 2. Reihe. Teil II. Lieferung 2): 99-186.

Janensch. W. 1914a. Die Gliederung der Tendaguru-Schichten im Tendaguru-Gebiet und die Entstchung der Saurier Lagerstätten. - Archiv für Biontologie 3 (3): 227-261.

- 1914h. Bericht über den Verlauf der Tendaguru-Expedition. - Archiv für Biontologie 3 (1): 17-58.

- 1925. Dic Grabungsstellen der Tendaguru-Gegend. - Palaeontographica. Supplement VII (1. Reihe, Teil 1, Lieferung 1): XVII-XIX.

- 1929. Material und Formengehalt der Sauropoden in der Ausbeute der Tendaguru-Expedition. - Palaeontographica. Supplement VII (1. Reihe. Teil 2, Lieferung 1): 1-34.

- 1955. Der Ornithopode Dysalotosaurus der Tendaguruschichten. - Palaeontographica, Supplement VII (1. Reihe. Teil 3. Lieferung 3): 105-176.

1961. Dic Gliedmaßen und Gliedmaßengurtel der Sauropoden der Tendaguruschichten. - Palacontographica, Supplement 7 (1. Reihe, Teil 3, Lieferung 4): 177-235.

Jenkins, F. A. Jr.. Crompton, A. W. \& Downs, W. R. 1983. Mesozoic Mammals from Arizona: New Evidence on Mammalian Fvolution. - Science 222: 1233-1235.

Jenkins, F. Jr., Gatesy, S. M., Shubin, N. H. \& Amaral, W. W., 1997. Haramivids and Triassic mammalian evolution. Nature 385: $715-718$.

Kent. P.. Hunt, J. A. \& Johnstone, M. A. 1971. The geology and geophysiscs of coastal Tanzania. - Natural Enviroment Research. Institute of Geological Sciences, Geophysical Paper 6: VI + $101 \mathrm{p}$.

Kemack, K. A. Kemack, D., Lees, P. M. \& Mills, J, R. E. 1998. New multituberculate-like teeth from the Middle Jurassic ol England. - Acta Palaeontologica Polonica 43 (4): $581-606$

Kielan-Jaworowska. Z. 1992. Interrelationships of Mesozoic mammals. - Historical Biology 6: 185-202.

Kiclan-Jaworowska. Z. \& Hurum, J. H. 2001. Phylogeny and systematics of multituberculate mammals. - Palaeontology $44(3): 389-429$

Kitlan-Jaworowska. Z. \& Ensom. P. C. 1992. Multituberculate mammals from the Upper Jurassic Purbeck Limestone Formation of Southern England. - Palaeontology 35 (1): $95-126$

Kitchin. F. 1.. 1929. On the age of the upper and middle dinosaur deposits at Tendaguru, Tanganyika Territory. Geological Magazine 66 (5): 193-220.

Parkinson. J.. 1930. The Dinosaur in East Alrica. 188 pp.. H. F. \& G, Witherby, London. 
Parrington, F. R. 1947. On a collection of Rhaetic mammalian teeth. - Proceedings of the Zoological Society of London 116 (3/4): 707-728.

Peyer, B. 1956. Uber Zähne von Haramiyiden, von Triconodonten und von wahrscheinlich synapsiden Reptilien aus dem Rhät von Hallau, Kt. Schaffhausen, Schweiz. Schweizerische Paläontologische Abhhandlungen 72: $1-72$.

Plicninger, W. H. von. 1847. Abbildungen von Zähnen aus der oberen Grenzbreccie des Keupers bei Degerloch und Steinenbronn. - Jahreshefte des Vereins für vaterländische Naturkunde in Württemberg 2: 164-167.

Russell, D., Béland, P. \& McIntosh, J. S. 1980. Paleoecology of the dinosaurs of Tendaguru (Tanzania). - Mémoirs de la Société Geologique de France, N. S. 139: 169-175.

Schrank, E. 1999. Palynology of the dinosaur beds of Tendaguru (Tanzania) - preliminary results. - Mitteilungen aus dem Museum für Naturkunde Berlin, Geowissenschaftliche Reihe 2: 171-183.

- 2000. Age and biogeographic links of palynomorph assemblages from dinosaur beds of Tendaguru (Late Jurassic, Tanzania). Actes du 4éme Symposium de Palynologie africaine (Sousse, Tunesie) 25-30 avril 1999, Geo-EcoTrop, Numéro Spécial 22: 141-146.

Schudack, M. 1999. Some charophytes from the Middle Dinosaur Member of the Tendaguru Formation (Upper Jurassic of Tanzania). - Mitteilungen aus dem Museum für Naturkunde Berlin, Geowissenschaftliche Reihe 2: 201-205.

Schudack, M. E., Schudack, U. 2001. Ostracods from the Middle Dinosaur Member of the Tendaguru Formation (Upper Jurassic of Tanzania). - Neues Jahrbuch für Geologie und Paläontologie, Mh. 2001: (in print).
Sigogneau-Russell, D. 1983. Nouveaux taxons de mammifères rhétiens. - Acta Palaeontologica Polonica 28: 233-249.

- 1989. Haramiyidae (Mammalia, Allotheria) en provenance du Trias superieur de Lorraine (France). -- Palaeontographica, Abt. A 206: 137-198.

- 1991a. First evidence of Multituberculata (Mammalia) in the Mesozoic of Africa. - Neues Jahrbuch für Geologie und Paläontologie, Mh. 1991 (2): 119-125.

- 1991b. Découverte du premier Mammifère tribosphénique

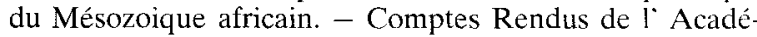
mie des Sciences de Paris, II 13: 405-414.

Sigogneau-Russell, D. Frank, R. M. \& Hemmerlé, J. 1986. A new family of mammals from the lower part of the French Rhaetic. In Padian, K. (ed.). The Beginning of the Age of Dinosaurs. Faunal Change Across the Triassic-Jurassic Boundary: 99-108, Cambridge University Press. Cambridge.

Sigogneau-Russell, D. \& Hahn, G. 1994. Late Triassic microvertebrates from central Europe. In Fraser, N. \& Sues. H.-D. (eds). In the Shadow of the Dinosaurs. Early Mesozoic Tetrapods: 197-213, Cambridge University Press. Cambridge.

Simpson, G. G. 1928. Mesozoic Mammalia. XI. Brancatherulum tendagurense Dietrich. - American Journal of Science 15: 303-308.

Smith, A. G., Smith, D. G., Funel B. M. 1994. Atlas of Mesozoic and Cenozoic coastlines. 99 pp, Cambridge University Press, Cambridge.

Unwin, D. M. \& Heinrich, W.-D. 1999. On a pterosaur jaw from the Upper Jurassic of Tendaguru, Tanzania. - Mitteilungen aus dem Museum für Naturkunde in Berlin. Geowissenschaftliche Reihe 2: 121-134. 